\title{
Domestic Expansion in the Iberian Kingdoms
}

During the last decades of the twentieth century, historians became convinced by the model of the economie immobile. This interpretation, heavily influenced by the Annales school, postulated an almost total absence of economic growth prior to the Industrial Revolution. ${ }^{1}$ The application of this model to the Iberian kingdoms-sometimes even avant la lettre-presented a highly negative interpretation of their economic development in the early modern period. Indeed, some authors even argued that the economy was dominated by an extensive agriculture which was fundamentally incapable of increasing its levels of productivity. The result was, it has been argued, a demographic increase that absorbed any expansion in production and which unleashed a crisis of Malthusian proportions at the end of the sixteenth century that was followed by recession. According to the assumptions of the new institutional economics as practiced by Douglas North, this outcome was also the inevitable result of the imperfect development of property rights in Spain; this imperfection was, in North's view, linked to the absence or extremely limited development of the capitalist system of land ownership (North 1981). Yet the realities of the 'Spanish case', which have so often been taken as irrefutable proof of these theories or models, in fact constitute excellent examples of

\footnotetext{
${ }^{1}$ See, for example, Le Roy Ladurie (1966). But the idea has been taken up again recently in a more sophisticated way by Clark (2007).

(C) The Author(s) 2019

B. Yun-Casalilla, Iberian World Empires and the Globalization of Europe 1415-1668, Palgrave Studies in Comparative Global History, https://doi.org/10.1007/978-981-13-0833-8_3
} 
the limits of these visions in explaining the behaviour of the economy. Above all, this is true in regard to Castile but also for most of the Crown of Portugal.

\section{A Technological Crossroad ${ }^{2}$}

Beyond economic considerations, a negative and pessimistic vision has long been very present in the different views on Iberian technological development. It is as if the technological delay characteristic of the Spanish and Portuguese industrial revolution of the nineteenth century had been projected retrospectively, giving rise to a sort of black legend according to which the development of useful knowledge had been always impossible in the Iberian countries. It is in part a consequence of the Enlightenment view of Spain and Portugal, expressed by Masson de Morvillers who, in a famous article in the L'Encyclopédie Méthodique, inquired: 'In two centuries, in four, or even in six, what has Spain done for Europe?' Spain, he added, is a country where it is necessary 'to ask priests for permission to read and think?' (Eamon 2009). In the last few years, however, historians of both science and technology have drawn attention to the capacity of sixteenth-century Spain and Portugal-frontiers in this aspect did not exist- to expand in these fields. ${ }^{3}$ They have also underlined the capacity of the peninsula to transfer this type of knowledge to the American colonies, with emphasis falling on the idea that these advances were vital to the control, conquest, and exploitation of these territories. But this process had its origins in Europe. Some of the keys to it will be developed in this chapter: the use of the mule, of agrarian instruments made from iron, leather, esparto grass, and canvass, all of which were to be evident in the development of rural industries in the Old and New Worlds. These were not revolutionary technologies but did take their place in this process of piecemeal, widely dispersed improvement whose overall impact would be important. Although no diachronic studies have been attempted, it is evident that the use of mills to grind flour advanced, with windmills being very prominent. Very probably Cervantes was venturing beyond the anecdotal when he set technology and knightly ideals as opponents and rivals in his two great

\footnotetext{
${ }^{2}$ A more elaborated and detailed version of what follows in Yun (2017). After writing these lines, I could read Cañizares-Esguerra (2017) who goes in depth on these ideas.

${ }^{3}$ See the cases studied in López Piñero (1979), Goodman (1988), and Barrera-Osorio (2006). For a brilliant defence, Eamon (2009).
} 
scenes evoking the windmill and fulling hammer: logically, don Quijote, a noble himself, identified these two monsters as his natural enemies. As we have seen, improvements were also made in the field of iron production. The introduction of techniques borrowed from German mining in the quarrying of silver and other sectors was a part of this process (Sánchez 1989). For obvious reasons, Iberian societies quickly adopted American dye products (indigo, the Campeche stick, or cochineal) that allowed it to make changes in the textile production processes.

If maritime expansion cannot be explained without reference to the technological and scientific progress achieved in fifteenth-century Iberian countries, then additional improvements in these fields were also the cause of the qualitative leap forwards made in the sixteenth century. The creation of the School of Pilots and Cartography in Seville, the Academy of Mathematics (founded by Philip II), the treaties on cartography such as those of Francisco Faleiro or Pedro de Medina and many other initiatives give the lie to the old stereotype of sixteenth-century Iberia being a society disinterested in technology (Goodman 1988). Something similar can be said of figures such as Juan de Monardes, a medic from Seville whose relatives were merchants involved in the Carrera de Indias and who brought him grasses from the New World so that he could study them and test their medicinal qualities. But this was just one part of a broader trend. What was really going on was the systematic amplification of forms of empirical knowledge gathering that would shortly culminate in Sir Francis Bacon's consecration of this type of scientific knowledge as a crucial part of modern thinking. In reality, Monardes' contemporaries included figures such as García de Orta, a converted Jew, medical doctor, and botanist from Portugal whose works would go around the world (Boxer 1963). ${ }^{4}$ Something similar could be said of engineering and hydraulics, which were set out in the works of Juanello Turriano (Zanetti 2012). The numerous proposals of the arbitristas were comparable in scope to modern patent applications (García Tapia 1990).

Though there are several examples in Joan Thirsk's influential study on English projectors (1978), scholars have systematically overlooked the fact that some English proposals for economic improvement and the modernization of its industry and mining sector depended upon introducing changes whose origins lay in Spain or Portugal. ${ }^{5}$ Perhaps not too many

${ }^{4}$ García de Orta, Tratado de las drogas, y medicinas de las Indias Orientales, Burgos, 1578.

${ }^{5}$ See, for example, some cases quoted by the author (Thirsk 1978): stockings knitted of silk (p. 45), hard white soap (pp. 53-4), and Spanish leather (p. 55). 
hasty conclusions should be drawn from an area that still requires more in-depth and detailed study, but it is important not to forget the known contributions when attempting to reach a balanced assessment of the technological evolution of early modern Iberian Peninsula.

It is also worthwhile to remember that Iberian naval technology was crucial to Dutch maritime development and that Castilian financial techniqueswith marked Italian roots-would spread in Europe in the sixteenth century (de Vries and Van der Woude 1997; Van der Wee 1967).

Though, as we will see, important advances took place, it is quite possible that a weak point of this technological development lay in the failure to adapt agrarian techniques, crucial for the economy of the time. Here, perhaps, improvements in organization were more important, even if they are sometimes difficult to separate from technological improvements, with which they often went hand in hand. In any case, it is important to remember the reasons for this progress, although here, again, more research is needed. A hypothesis can at least be presented. The Iberian Peninsula combined two necessary conditions: it was, first, the crossroads of technological development and cultural cross-fertilization; and, second, technology was vital to maintaining the empire. Oceanic expansion had been possible thanks to the meeting of different cultures (Chap. 1). And this continued to be the case. Being the centre of a composite monarchy spread out across Europe, the enormous power of the King of Spain and his needs generated a strong gravitational pull upon 'mechanics', inventors, and intellectuals from across the world. Juanello Turriano was from Cremona. Monardes had one eye on America and the other on Castile. De Orta was born in Castile, emigrated to Portugal, and travelled to Goa. The Welser and the Fugger, who carried American and Iberian mining forward, gathered their knowledge in Germany, the most advanced country of its time in this sector. Even the procedure for the amalgamation of mercury came from a German, who put it into practice in America (Sánchez 1989). And we cannot overlook the fact that many of those who proposed 'remedies', reforms, and patents-sometimes it is difficult to differentiate between them (Yun 2016)-were Italians and Germans, Flemish, and French. Not all of these proposals had much sense, of course. The term 'arbitrista' carried the connotation of madness or opportunism (Yun 2016). But the very fact of their existence demonstrates an intellectual effervescence. This circulation of techniques and inventions, the sponsorship of hybrid forms that brought about new knowledge, is typical of the period in which the word 'invention' was not taken to be that 
different from the term 'imitation' and was understood as such in many areas of Europe, where what was presented as an invention in one country was very often merely a copy of something common elsewhere.

The type of networks that allowed these new inventions and forms of knowledge and expertise to circulate was also highly important for other activities. In part they were similar to the webs through which artisans moved (Epstein 2002). These would be very prominent in relation to mining, which benefited from being a sector with an almost non-existent degree of guild governance, thus ensuring a higher degree of receptivity when faced with innovation. But this was also true in relation to the circulation of men, science, and ideas through princely courts and noble households. This was the case in the circuits that spread the new knowledge on mining, hydraulics, mathematics, and watchmaking and in which Juanello Turriano moved (Zanetti 2012). The same was true of many other specialists and inventors who proposed patents to the monarchy. But the king was also concerned, as were institutions such as the Council of the Indies, to develop new types and fields of knowledge, often being conscious that these areas were very poorly represented in the universities. The transfrontier character of the monarchy and its elites (Chap. 4) pulled in this same direction, favouring the circulation of knowledge. The presence of books on geometry, mathematics, geography, and history (disciplines intimately linked to war and to natural philosophy) in noble libraries is eyecatching. Questions of personal and familial prestige aside, this was a type of knowledge that was not confined to the nobles and that, moreover, revealed an interaction with the 'mechanics' and other intellectuals who played such a role in the art of war. These contacts were especially intense with Italy, the most important centre for the production of scientific and technical knowledge of the time. And this helps us to understand a phenomenon that until recently was largely overlooked by scholars.

\section{Local Institutions, Regional Ecosystems, AND Land PROperty Rights}

But if the capacity to produce and, above all, to adapt and recycle technology was one of the keys to Iberia's economic and geographic expansion, then this growth can only be understood through a description of the different regional economies and land property rights. In the end, this economy was fundamentally a regional one conditioned by its physical characteristics. 
In an area marked by an enormous diversity of geographical and institutional features, it perhaps makes sense to begin with an idea of the vast differences that existed between productive ecosystems and regional institutions, many of which had emerged during the centuries of the Reconquista. This disparity was manifested in many different forms of productive organization, wealth distribution, and social domination which were to a large degree the result of the interplay of the three basic institutions in rural life: the peasant family, the rural community (often organized in concejos and câmaras in Castile and Portugal, respectively), and the señorío.

The so-called Atlantic Spain, the area from Galicia to Navarre in the north of the country, was an ecological unit. These mountainous regions all shared a climate of mild temperatures and frequent rainfall spread over the calendar year. Their abundant water supply, extensive natural grasslands, and thick woodland meant that they were very different from the Spanish and Portuguese interiors (García Fernández 1975). Yet, these general features notwithstanding, this was a very heterogeneous region. In Galicia and Asturias, the peasant community had converted itself into the basic unit for regulating and exploiting agrarian resources (Saavedra 1983, p. 17, 1993, pp. 428-51). This function was performed by the concejos, or rural communities sometimes made up of a number of different villages or settlements and sometimes by one single nucleus that organized social and economic life in its territory. The concejos regulated crop rotation patterns and controlled the exploitation of the ample and leafy woodlands, which were often held as communal property. With certain logical differences, this situation was reproduced in Navarre and in the Pyrenean valleys, where communities frequently grouped together to exploit the available resources (Zabalza 1994, pp. 65-7). The Basque Country was, however, slightly different in this regard, even if it did not break with the model entirely. Here the extended family unit was crucial — in many senses even more than the rural community - and the majority of these functions were organized around the farmhouse and on a smaller scale. ${ }^{6}$

In spite of the role of the concejos, and in marked difference to the situation on the Meseta, it is clear that the role of the peasant community as a mediator in the distribution of products between the peasantry and its land-

\footnotetext{
${ }^{6}$ Even in the fifteenth century, this area had seen the emergence of ties of association between different towns, guaranteeing a better defence of their common interests and a better regulation of the mountainside spaces (Fernández de Pinedo 1974, p. 62).
} 
lords had been reduced. In Galicia the concejos' struggle against the rights of the landlords had led the latter to prefer to receive payment of rents in enfiteusis on a lifetime basis or even as a perpetual lease, with the individual famers paying them directly (Saavedra 1985, p. 443; García Fernández 1975, pp. 190-7). Here, again, the Basque Country was the exception to the rule, as almost half of its peasants were landowners and farms were generally rented on shorter-term leases. ${ }^{7}$ The result across Atlantic Spain and the western Pyrenees was the stability of the peasant exploitation, based on extended family networks that were strengthened by the proclivity of the landlords, who were predominantly ecclesiastical institutions, to rent lands as units with all of their attributes (houses, space for livestock, etc.) to families and married couples. This created rural communities in which social inequalities were much less pronounced than on the flatlands of the Meseta. But at the same time, these conditions strengthened the position of a middling group of hidalgos and intermediate nobility that lived in the more important centres such as Oviedo and Santiago. Shortly this social group would benefit from lands ceded also a foro (through enfiteusis) from the great ecclesiastical institutions and lay landowners. This development allowed such middling aristocrats to take part in agrarian production and converted them into a fundamental link in the chain of power and the exercise of coercion on the local level. Even in the Basque Country, a midranking sector, whose fortunes originated in commerce, was consolidating its position in networks that distributed agricultural products (Villares 1982, pp. 77-95; Fernández de Pinedo 1974, pp. 58-9).

This being a zone of abundant year-round rains, these factors led to demographic and productive growth. In some areas this growth was based upon a 'pre-revolution' of millet, which supplemented the cultivation of other cereals such as wheat, barley, and spelt. Moreover, the abundance of woodlands and mountain pasture, together with the precise regulation of the use of farmable soils, allowed agriculture and livestock farming to thrive side by side, a development which the consequent high quantities of animal effluent further encouraged. The high quantity of woodland resources and the resulting opportunity to feed both livestock and people provided a large number of additional assets to these peasant economies and limited the effects of bad harvests (García Fernández 1975). A number of auxiliary activities, some of them encouraged by the urban development of the Meseta,

\footnotetext{
${ }^{7}$ For the Basque Country, García de Cortázar (1988, pp. 262-3).
} 
Table 3.1 Demographic growth in sixteenth-century Iberia

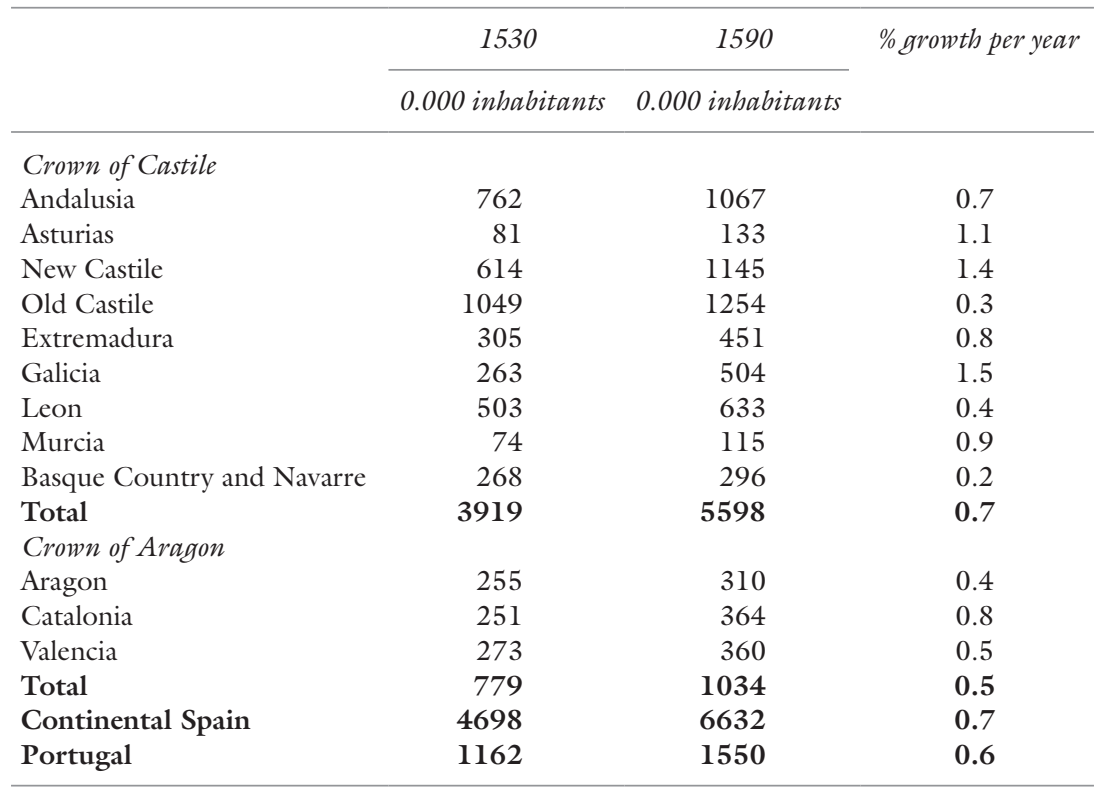

Sources: My own elaboration from Nadal (1984) and Miranda (2016), applying to Portugal the ratio vecino/inhabitant of Nadal: 4 instead of 4.3

supplemented incomes: transport; short-term migration to the peninsular interior in search of wages during the harvest of cereals and viticulture (from July to September), iron and carbon production, and trade in leather, woods, fish, and other local products to the more urbanized areas of the interior. ${ }^{8}$ Population growth, if quite meagre in the Basque Country and Navarre, was highly notable in Asturias and Galicia, where clear demographic spurts occurred between 1530 and 1580, despite this being a period of considerable emigration (see Table 3.1 and Map 3.1).

These characteristics, common across Atlantic Spain, were also present in some of the foothills and more humid climates with a rich vegetal cover of the Duero Valley, such as the sierras of Sanabria, the mountains of León and Burgos, the high regions of Soria, or the foothills of the north of the central system (above all Ávila and Segovia). But overall the central platean

\footnotetext{
${ }^{8}$ Saavedra (1983, p. 50, 1985, p. 18), Anes (1988, p. 39), Lanza (1991, pp. 121, 143-8).
} 


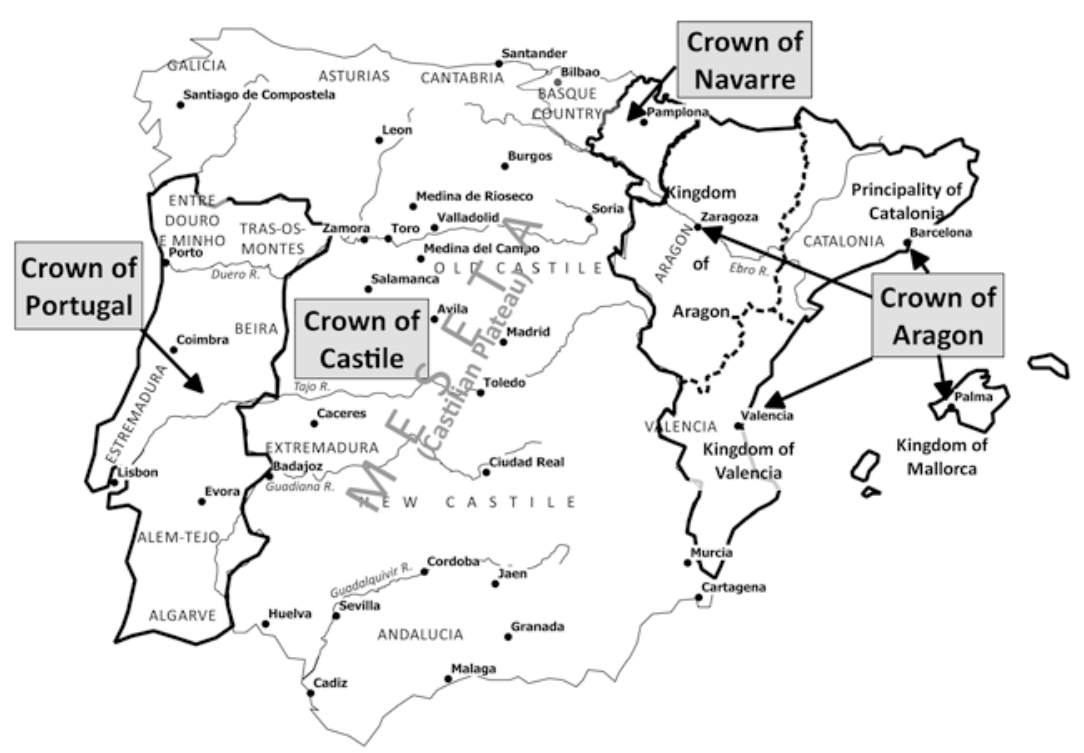

Map 3.1 Iberia in the sixteenth century

(the Meseta) - the extensive flatlands of drier climate and more extreme temperatures that stretched from the mountains of Cantabria and the Sierra Morena through the valleys of the Duero, Tajo, and Guadiana rivers - presented a very different panorama. Having said this, allowance must be made for the diversity of such a big region.

The mononuclear concejos that dominated the north of the Duero were succeeded by the poly-nuclear 'communities of town and land' (comunidades de villa $y$ tierra) to the south of the river. The latter were extremely hierarchical organizations where the 'town' controlled economic activities not only within its own estate but also within those of the surrounding rural communities. Here the rural community played also a crucial role, organizing and regulating the exploitation of natural resources, setting the crop rotation patterns (normally based on a cycle of just over a calendar year and in which cereals were the staple crop), and alternating between sheep farming and the cultivation of the vine and the system of rotating cornfields (derrota de mieses). This entailed the opening up of the agricultural farmland immediately after the cereal harvest by August so that local herds could graze on the stems and stubble and fertilize the land with 
their excrement. The result was an open field system organized by the community that both defended vineyards and oversaw systems of local transhumance running to the nearby mountains. In many cases a number of councils or communities of one comunidad de villa y tierra formed alliances in order to exploit their pastures and woodlands, thus increasing their economies of scale. Moreover, many of these communities counted upon extensive tracts of unfarmed lands within their municipal estates; these terrains either had no owner or belonged to the king and thus could be used by farmers or livestock breeders with the council's permission (Vassberg 1983).

The role of the rural council was also significant in the distribution of wealth between landlords and peasants. The quantities of wealth channelled through them on the Meseta were far greater than in their equivalents in Atlantic Spain. These institutions often undertook to collect the royal or seigniorial taxes such as the alcabalas and the tercias from the inhabitants. Frequently the community, as a corporation, had obtained the right to use seigniorial lands and was charged with organizing their use and transferring the tribute or payment to the landowner for these privileges. The community operated, therefore, as the basic intermediary between the rural society and the landlords, who in many cases enjoyed the right to appoint to local authorities and to administer justice at a basic level-in other words, they exercised coercive power. ${ }^{9}$

This is not to deny, however, the existence of a direct relationship between great lords on the one hand and individual farmers on the other. On the contrary, this arrangement was common and even led to the emergence of a wide variety of forms of direct relationships between the tenant and the landlord, running from enfiteusis to the short-term renting of properties belonging to the nobility or Church. Many seigniorial properties included pasturelands and woodlands that were never rented or ceded to councils but instead exploited directly by their owners for their livestock economy. ${ }^{10}$ This system was even more common in the extensive zone to the south of the Tajo, where large landowners controlled huge flocks (particularly sheep)

\footnotetext{
${ }^{9}$ In Castile at this time, 'the farmers did not speak individually, but instead as natives of a municipal corporation; kings and lords communicated with their mayors more than with individual subjects' (Nader 1990, p. 18).

${ }^{10}$ See the case of Guadalajara in Gómez Mendoza (1978, pp. 88-92) or, for a different form, the case of the county of Feria in Badajoz and the pasturelands of the count of Belalcázar in la Puebla (Cabrera 1977, pp. 277-9).
} 
and enormous grazing lands. Many proprietors of this sort- the Monastery of Guadalupe, the archbishopric of Toledo, or the Military Orders-were closely tied to the Honoured Council of the Mesta (see Chap. 1). ${ }^{11}$

Further to the south, this large-scale property ownership and, therefore, social inequalities became increasingly common. Although the ecological possibilities of this zone, in which summers are considerably warmer and rains more scarce, were more limited, these high levels of inequality compelled the peasantry to diversify its economic undertakings, resulting in the development of domestic industry, transport activities, and alternative agriculture in general. These adaptations provided families with additional incomes and allowed them to overcome the basic inequality in land ownership. These forms of alternative agriculture or peasant industries were viable thanks to the emergence of peasant markets regulated by the more important towns using privileges conceded by the local lord or the king himself. ${ }^{12}$ Markets of this sort constituted centres of commercialization for the wools of small local herds as well as for linen, esparto grass, hemp, and basic crude cloths. Finally, these rural markets also served as the focal points for myriad transport activities (Vassberg 1986, p. 238).

The Mediterranean and continental climate of the interior had lower rainfall levels than Atlantic Spain. Nevertheless, in these zones there thrived a cereal agriculture whose yields matched the European average and existed side by side with exceptional numbers of livestock, particularly sheep, which were grazed not only through transhumance between different ecosystems but also (and above all) between different municipalities (Bishko 1978). This agro-pastoral economy was noticeable for forms of communal organization and the co-ordination of resources in both the low hills and flatlands. Furthermore, despite the false stereotype of this being a zone completely dominated by the designs of the all-powerful Honoured Council of the Mesta, it is clear that, the main transhumance routes and certain pasturelands excepted, it was the local community that exercised the greatest influence over land use. This was also, of course, an important area for vineyards,

\footnotetext{
${ }^{11}$ Ruiz Rodríguez (1993, p. 27); Klein (1979, p. 73); López-Salazar (1987, pp. 9-18).

${ }^{12}$ The term alternative agriculture alludes to a series of non-basic crops of considerable, if ultimately marginal, importance and which became a valuable source of income for many peasants in early modern Europe (Thirsk 1997). Noel Salomon refers to a similar phenomenon, placing emphasis upon artisanal production, viticulture, and transport as 'peasant industries', activities providing auxiliary incomes to peasant economies (1982, pp. 33, 111 , 291-301).
} 
a labour-intensive crop, whose cultivation was undertaken thanks to the protectionist by-laws of the rural centres. The greater cities further to the south, where considerable distances separated the inhabited centres from the farming areas, saw important changes. These were brought about by the replacement of the ox by the mule, a quicker beast of burden and so one capable of ploughing more rapidly and travelling to more distant areas-an important consideration given the progressive concentration of property and the dispersion of plots of cultivated land. The diffussion of the mule constituted, probably, one of the more important technical advances implemented from the fifteenth century.

The predominance of hereditary systems based upon the division of property among all of the peasant family's sons resulted in patterns of early marriage. Unfarmed and communal lands were widely accessible; many councils specifically reserved these for local married couples or widows. These conditions resulted in a zone of unquestionable demographic vigour, with high levels of population mobility.

Seigniorial incomes, boosted by their jurisdictional rights and the consequent increase in landlords' capacity to collect excises, were enhanced by lands rented on short-term, renegotiable leases and, at times, as enfiteusis. In some cases, owners directly exploited their estates (above all, this was true for pastureland and meadows). But the basis of their income lay in the tercias and alcabalas paid by the peasant communities as institutions. ${ }^{13}$ In many cases the uneven division of productive resources had created a rural elite of farm workers (labradores, a sort of yeomen) who regulated the use of resources belonging to the municipal institutions.

Thus, the Meseta was a dynamic and growing region. The solidity of peasant economies in the Duero Valley and mounting urban development favoured the growth of production and population, which was only limited by its high demographic density and elevated rates of land occupancy (see Table 3.1). ${ }^{14}$ Further south, in New Castile, Extremadura, and Murcia, less solid peasant economies, with lower levels of urban density, were blessed with

\footnotetext{
${ }^{13}$ As it has been said before (Chap. 1), the tercias were the 2/9 of the ecclesiastic tithes and the alcabala an ad valorem tax on commercial transactions. Both were often ceded to the jurisdictional seigniors.

${ }^{14}$ With demographic densities of 16 inhabitants per square kilometre, the highest of the peninsula in 1530 , the population growth would have been $0.3 \%$ annually (Table 3.1 ).
} 
enormous quantities of exploitable land as yet unfarmed (their densities around 1530 were 8.4, 7.3 and 2.8 inhabitants per square kilometre, respectively), and this would attract new settlers from the northern areas who sought small plots, a salaries, or, more commonly, both. Commercial development, which in Murcia's case depended upon distant and sometimes even foreign markets, would be one of the keys to growth across this broad swathe of territory, as can be understood through an analysis of population figures.

From a political and institutional perspective, the rural communities of Andalusia also enjoyed extensive legal and coercive powers. With a more concentrated urban and semi-urban population, the ample communal estates offered abundant opportunities in the foothills to the north of the region and, indeed, in upper Andalusia in general; but there were also many opportunities in the lowlands of the Guadalquivir. These lands were allocated as small plots, thus lending a degree of solidarity to the humbler peasant families and anchoring the population to the soils. ${ }^{15}$ In addition there were a large number of unfarmed and council lands, communally owned and managed by the municipalities. These were dedicated to livestock farming or the production of wool. The community constituted, therefore, an important element in the exploitation of resources in Andalusia. It also played a significant role in the transfer of incomes to the landlords, who claimed alcabalas, and monopolies on slaughterhouses, flour and oil mills, and taverns, as well as taxes on the passage of commodities. The collection of these revenues was entrusted to the municipal authorities or controlled through the jurisdiction that the seigniors exercised over rural centres. ${ }^{16}$

Yet, this region had the most highly developed forms of large estates (latifundia) belonging to the great lords, the clergy, and even the midranking nobility. From the fifteenth century onwards, the organizational basis of these latifundia was the country house or cortijo, the centre of an extensive farmstead boasting granaries, various kinds of mills, stables, a courtyard, pens, and a residence where the proprietor or tenant would live (Collantes 1977, p. 115). Large enterprises of this kind were usually leased out over six-year periods in exchange for rents paid in specie or coin. In some cases they were directly farmed by the landowner. Their logic was

${ }^{15}$ Cabrera (1977, p. 350), Vassberg (1986, pp. 168-9), and Mata (1987, vol. I, pp. 180-6).

${ }^{16}$ Atienza (1987, pp. 234-79). For areas of the Sierra Morena, see Cabrera (1977, pp. 250-330). 
therefore very different from those of the family units that distinguished other areas to the north. In Andalusia, and more in particular in the Guadalquivir Valley, on the other hand, salaried seasonal work predominated; agricultural surpluses were sold in the highly populated urban centres or even sent to foreign markets. But there also existed a network of smallholdings; additionally, many small plots of land belonging to the local lord or municipality were leased out. These smaller exploitations supported a working population employed seasonally on the great estates, thus serving as a means of externalizing maintenance costs.

It would, however, be wrong to speak of uniform conditions across the region. On the contrary, a wide range of characteristics were found in lower and upper Andalusia. In general terms, however, Andalusia appeared to be a society characterized by levels of inequality that were even more marked than those of the north of the peninsula, and this was true not just in economic terms. Because its population was continually augmented by immigration, the lower strata of peasants played a relatively insignificant role in local government. Above all, this was the case in the large towns, where the councils were controlled by local oligarchies that were never entirely independent of the nobility. Familial or client relationships united these different factions with the great nobles, creating a very fluid and complex dynamic.

As in the zones of La Mancha and Extremadura analysed above, the abundance of both available land and salaried work in the great estates attracted immigrants from the north of the peninsula. The constitution of the great cities stimulated both the commercialization of the surpluses of these huge estates and their dynamism in attracting settlers. The resulting demographic growth, if less dramatic than in New Castile (in part because of the loss of people sailing for America), was nevertheless clearly evident in the economic dynamism of this large region (Table 3.1).

An advanced form of rural council organization that formed an important link in the regulation of productive resources and the transfer of landlord incomes had also developed in the region of Aragon. The concejos collected the pechos, taxes on the members of the peasant community, on behalf of the landlord. They also collected the symbolic rights inherent in the lord's jurisdiction as well as monopoly rights on slaughterhouses and mills. Often councils had been granted the control of communal lands conceded by the seignior in exchange for a censo enfitéutico or 'treudo' (Colás and Salas 1982, pp. 33-42; Colás 1988, pp. 24-6). However, in Aragon the lords' income also included revenue streams derived from a more direct and unmediated 
relationship with their vassals in which the councils often played little or no part. There were also full or allodial properties, rented to peasant families or farmed directly by the landlord using hired workers and, in the case of the Moriscos, groups who were compelled to serve their lord with personal labour whenever this custom had not been commuted to direct payment in money. But this type of property, fully owned by the seignior, was less developed than in Castile, and, whether it was with the intervention of the community or without it, Aragon was 'the world of shared proprietorship'. A long time previously, the lords had handed over their lands in return for a 'censo enfitéutico' or 'treudo', sometimes contracted out in perpetuity and paid in money, coin, or by a portion of the yield (Colás 1994).

The vestiges of servitude and the importance of shared property differentiated Aragonese from contemporary Castilian landownership, but the major difference stemmed from the evolution of the jurisdictional power of the lords. Jurisdictional prerogatives in themselves hardly generated any economic income; however, here, as in Castile, certain landlords' possession of absolute jurisdiction converted them into judges whose decision could not be appealed, thus marginalizing the authority of the king himself. The lords' capacity for enforcement and the control of violence was even more marked in Aragon than in the Crowns of Portugal and Castile.

Shared property, which acknowledged the peasants' right to cultivate the land, and the abundance of communal lands helped to stabilize both Christian and Morisco peasant family economy. Yet peasant society remained characterized by marked internal differences, with many farmers continuing to live in small holdings often based upon an intensive agriculture depending upon irrigation systems and auxiliary activities directed towards the market (crops such as saffron, the vine and olive, etc.) (Atienza 1988, p. 147; Colás and Salas 1982, p. 38).

The combination of absolute seigniorial jurisdiction and the presence of the Morisco population, whose legal status was weaker, contributed to the formation of a society in which the power of the nobility was almost unlimited in terms of both its control over vassals and its capacity to interfere with the organization of the economy.

Growth was, therefore, limited in Aragon by its relatively inflexible economy, which in turn can be understood as a result of the shackles of feudal origin, the exercise of noble jurisdiction, and the minimal level of urban development. Annual demographic growth was thus restricted in the kingdom to rates of around $0.4 \%$ - and this despite its low demographic densities (5.3 habitants per $\mathrm{km}$ squared) (Yun 2004). These 
characteristics may be seen, in part, as a consequence of the juridical insecurity of peasant existence and the extremely arbitrary justice to which seigniorial authorities submitted rural communities.

The communities of the kingdom of Valencia also 'possessed a great vitality' (Ardit 1994, vol. II, p. 190). They constituted centres around which social and economic life was organized. But, at the same time, the majority of the land belonging to the seigniors and to the large ecclesiastical institutions was rented out, either in enfiteusis or as leases, directly to farmers with no form of intermediation by the community (Peris 1989, p. 86). In some areas, such as those around the Huerta, a region where the irrigation network had been extended, the use of plots of land conceded in enfiteusis served to reduce the differences that had emerged from the inequitable division of peasant property. The result was a situation of great variety in the distribution and structure of farmlands (Furió 1995, p. 308).

In general the coastal zones and those near the capital witnessed a form of agriculture that was highly influenced by the market and consequently was dedicated to commercial products. This was especially true in areas around the region of Huerta, where an intensive farming of fruit, mulberry trees, and vegetables predominated, and in the coastal zones and those near the capital. From the sixteenth century, viticulture was spreading into the dry lands (those without guaranteed irrigation), producing raisins, almonds, and crops exported for industrial use (Halperin 1980, pp. 21-2, 26). These trends contributed to the diversification of peasant incomes and fed economic growth. In many areas, the 'decision on the use of the fallow land was made by individuals, not collectives, and depended on the quality of the terrain'. Farmers who directly exploited their soils possessed thus 'an unlimited degree of control over their lands' and 'an almost-absolute liberty in deciding which crops to grow' (Ciscar 1977, p. 44; Peris 1989 , p. 37). This progress was fed by the availability of capital from cities, merchants, and even the aristocracy, as in the case of the Genoese interested in sugar cane production, silk, and other products or the duke of Gandia, who invested with the aim of expanding the cultivation of these crops. Another positive factor lay in the need to provision the capital, Valencia, which was growing because of international commerce (Chap. 1) and the exploitation of crops such as sugar, silk, and other products. Cereals were sourced from across the Mediterranean (and especially from Sicily) and from Old Castile.

As in Aragon, the jurisdiction of the landlords had developed significantly in Valencia and even offered a certain degree of autonomy from the 
king's legal authority. This jurisdiction was wielded through the authorities named by the community government and played an important role in the transfer of rents to the landlords who received part of their income from their land through direct exploitation but whose principal income derived from lands conferred upon tenants in censos. Another of the most important income streams was the tercio diezmo and regalias (rights of the king ceded to the landlords) and privileges linked to jurisdiction that were paid by the community as a whole. ${ }^{17}$

These trends resulted in highly diverse agrarian systems, ranging from the extensive exploitation of livestock (in the interior uplands) to the intensive agriculture of the meadow or huerta. In all cases they were exercised with vigorous forms of feudal jurisdiction. But this was also a highly flexible agrarian economy, very much orientated towards the market, where enfiteusis served as the basis for improvements in production undertaken by the peasants enjoying perpetual use of the land that they farmed. In this context, the region's commercial development around the capital sparked a growth surge that was clearly manifested in the figures detailing demographic progress. ${ }^{18}$

Similar paradoxes can be found in Catalonia, where, nevertheless, the landowners' vigour was considerably less noticeable. The idea first outlined by Pierre Vilar (1962, vol. I, p. 562), that the Sentence of Guadalupe brought about 'a feudal restoration and a social pact that confirmed feudal revenues' (Serra 1988, pp. 46-9) and created a new social equilibrium in the countryside (see Chap. 1) has been widely accepted.

The basic motor of late fifteenth-century growth does not appear to have been the rural community. As in all of Europe, it continued to be the fundamental unit upon which the jurisdictional power of the landlord and king was exercised through local authorities and delegated legal representatives. But, in general, their involvement in economic life was less common than was that of their counterparts in Castile or the region of Aragon. On the contrary, the key to both the rural economy and Catalan agrarian expansion was the family, always tightly tied to the land through the mas (Elliott 1963, pp. 28-31) and whose role had been strengthened by the Sentence of Guadalupe to the

\footnotetext{
${ }^{17}$ Ciscar (1977, pp. 228-35), Ardit (1994, vol. I, pp. 92-3).

${ }^{18}$ According to Ardit, the population may have increased between $0.25 \%$ and $0.41 \%$ annually between 1510 and 1609 , depending on the population at the starting point (1994, vol. I, p. 19).
} 
extent that it consecrated the property rights of the peasant elite and established the precedent that only by its abandonment could a property return into the hands of the landlord. The crisis of the fourteenth century and the subsequent concentration of lands appear to have led to the increase in the habitual size of the mas (Vilar 1962, vol. I, p. 577). These larger dimensions brought about an improvement in their capacity to mobilize productive resources. Inheritance rights tended to reserve the lion's share of goods for one of the sons (usually the eldest), and this custom also favoured the stability of the family farm, even if it prejudiced the other children. This explains the coexistence beneath the same roof of not only the head of the family but also a number of his brothers and sisters, who thus constituted a complex variant of the family unity and one capable of mobilizing a large amount of labour (Elliott 1963, pp. 28-31). But this was not the only consequence of the Sentence of Guadalupe. At the same time, the establishment of this strata of masovers (an elite of property owners exploiting its rights over the mas) had contributed to the crystallization of another wider sector of small peasants - the other side of the coin-who found themselves compelled to rent the plots of the mas or to work upon them for a salary during the periods of greatest agricultural activity (Elliott 1963, p. 30).

These conditions gave rise to a form of peasant society with a high capacity for production. From an early point, it supported the emergence of masias, assisted by the security and permanence of property rights. In many cases this was fed by important investments in fixed capital (buildings, granaries, and stables) and brought about a reorganization of farms which, in turn, would have an impact upon production. The renting out in enfiteusis of plots of the mas to small peasants served to tie the workforce to the land and consolidated the position of the humblest groups in rural society, thus feeding demographic and agrarian growth. These developments were accompanied by the expansion of industrial and marketorientated crops that diversified both resources and sources of income for the rural population. The result of all of these changes was the expansion of the vineyard, or the increasing exploitation of millet, rice and vegetables, dry fruits, hemp, silk, and saffron (the latter products tied to the commercial networks established by German merchants trading through Perpignan and the fairs of Lyon). Catalonia, therefore, supported relatively dynamic and flexible agrarian systems, in which polyculture was made possible around the masia, whose prosperity was based 'upon the size and the variety of its production' (Vilar 1962, vol. I, p. 584). 
The collection of revenues was very seldom channelled through the community as such, and by the sixteenth century, all prospect of resurrecting the personal remensa (the payment due to the lord for the chance to leave the land) and many of the feudal rights claimed by landlords in the previous century had vanished. This led to a higher degree of security for their vassals and tenants (see Chap. 1). But, at the same time, the landlord claimed a number of important prerogatives which allowed him to seize an important part of the surplus production and to participate in the agrarian growth brought about by the extension of this ever-more flexible and varied agriculture (Duran 1982). Yet the overall equilibrium was not threatened by the enforcement powers wielded by the landowners; on the contrary, and in comparison with previous periods, these seigniorial prerogatives in fact limited the landowner's propensity to commit abuses and so came to form the basis of a new period of demographic and economic growth. Catalonia's population grew at an annual rate of $0.8 \%$ from 1530 to 1590 (Table 3.1). As was the case in other southern zones of the Iberian Peninsula, one of the reasons for its attractiveness to settlers from the north - in this case, the French side of the Pyrenees-lay in a combination of institutions, natural resources, and economic factors.

More than an ecological unity, Portugal was a set of regions made up of very distinct physical components. The differences are very marked: from the mountainous zones of the north, such as the provinces of EntreDouro-e-Minho and Tras-os-Montes, with their Atlantic climate, to the plains of the Alentejo and even the more mountainous zone with the highest rates of precipitation, such as the Algarve in the South. The role of the concelho (equivalent to the Castilian and Aragonese rural council or concejo) was important across the country. The system for the concession of privileges established by the Portuguese kings was governed by the idea that the monarchy should not grant excessive power to any one nucleus. It had, however, given rise to a more homogenous and less hierarchical political sphere than in Castile, as above all differences were caused by economic activities (Mattoso 1997, pp. 205-40). Moreover, in overall terms long-term leasehold (enfiteusis) had developed to a significant extent during the last centuries of the Middle Ages, to a considerable degree due to the stagnation of the population at very low levels between 1350 and 1450 and the consequent need to attract settlers to many zones of the country (Mattoso 1997). The north of the country had seen the establishment of more seigniorial estates, while in the south the great councils were abundant, with extensive municipal estates and sometimes existing under 
the jurisdiction of the Military Orders. This difference between the north and south - and above all between the north and south of the Tagus River-was perhaps one of the most important traits of the Portuguese economy. In any case, the farming system regulated by councils predominated across the country, with rotation timetables for cereals, at times combined with the vine, olive, and ovine livestock. The north, being more populated, was characterized by a variety of crops and natural resources that permitted a higher density of population, which was well above the peninsular average. This being the case, it witnessed the strongest forms of emigration, above all towards the Tagus Valley, Lisbon, the settlements of the lower Tagus Valley, and even in part towards Alentejo, to the extent that its poor soils allowed such a movement. Moreover, in addition to the diversity of resources, the north of Portugal was more open to the Atlantic through Lisbon and the cities and towns between Porto and the frontier with Galicia. This was a region where the impact of the oceanic and commercial expansion would have a notable effect.

The poor soils and arid summer climate of Alentejo between the Tagus and the Guadiana meant that it was less conducive to economic activities. Its very low demographic densities (among the lowest of the peninsula), the concentration of commercial activities to the north of Lisbon, and the coastal characteristics meant that its openness to and interaction with the sea were very limited, despite its boasting almost $300 \mathrm{~km}$ of shoreline between Lisbon and the Cape of St. Vincent. Here wheat and transhumance livestock farming (above all in the frontier zones with Castile) had a relatively greater importance (Magalhães 1997, pp. 230, 239), and it is not surprising that pasturelands were hired out to Castilian shepherds. But the chances of the commercialization of peasant production were very modest, not only because of the absence of an attractive outside market but also because of the low density of the urban mesh that was, in Castile, a crucial factor in growth.

\section{Economic Expansion in a Pre-Industrial Society}

The expansive cycle that had begun in the last decades of the 1400s was sustained throughout the following century. But what type of expansion was achieved? What were its dimensions and limits? Did it fit the model of an extensive agriculture surrender to diminishing marginal returns or yields whose surplus production is systematically absorbed by the upward evolution of land rents or seigniorial extractions, the result of which is a debilitating tension between resources and population? 


\section{Growth and Development}

It should immediately be stated that the present-day definition of modern economic growth, based upon a continuous process of expansion in per capita product, must be applied with great caution to pre-industrial economies. Even if they did not achieve this increase of income per inhabitant, in economies which existed on the margins of subsistence, success lay in the simple production of more foodstuffs that allowed them to support more inhabitants. But the Iberian cases allow us to go further than this.

The population increase in Spain is, without doubt, evident and even more accelerated than in most parts of Europe, as can be seen from Table 3.2, which presents some corrected numbers for Spain, following the calculations of J. De Vries and my own estimates by using data from Nadal (1984) and Miranda (2016). The population of Portugal also had risen from some 1.2 million inhabitant households around 1527 to some 1.5-1.6 million inhabitants at the end of the century (See Serrão and Marques 1998, p. 44, Graph 1; Miranda 2016). Whatever the point of reference, it is clear that the Spanish and Portuguese population increased

Table 3.2 Demographic growth in sixteenth-century Europe

\begin{tabular}{|c|c|c|c|c|c|c|}
\hline & \multicolumn{5}{|c|}{ (Millions of inbabitants) } & \multirow[t]{2}{*}{$\%$ growth per year } \\
\hline & 1500 & 1530 & 1550 & 1590 & 1600 & \\
\hline Scandinavia & 1.5 & & 1.7 & & 2 & 0.28 \\
\hline England & 2.3 & & 3.1 & & 4.2 & 0.86 \\
\hline Scotland & 0.8 & & 0.9 & & 1 & 0.22 \\
\hline Ireland & 0.8 & & 0.9 & & 1 & 0.22 \\
\hline Holland & 0.95 & & 1.25 & & 1.5 & 0.45 \\
\hline Belgium & 1.25 & & 1.65 & & 1.3 & 0.04 \\
\hline Germany & 12 & & 14 & & 16 & 0.28 \\
\hline France & 16.4 & & 19 & & 20 & 0.19 \\
\hline Switzerland & 0.6 & & 0.75 & & 0.9 & 0.4 \\
\hline Italy & 10.5 & & 11.4 & & 13.1 & 0.22 \\
\hline Spain & & 4.69 & & 6.63 & & 0.7 \\
\hline Portugal & & 1.2 & & 1.5 & & 0.6 \\
\hline Austria-Bohemia & 3.5 & & 3.6 & & 4.3 & 0.2 \\
\hline Poland & 2.5 & & 3 & & 3.4 & 0.3 \\
\hline
\end{tabular}

Sources: My own elaboration from De Vries (1994, p. 13) and Nadal (1984, p. 74, Table 9) and Miranda (2016), using a ratio vecino/inhabitant of 4 for Portugal (see Table 3.1) 
noticeably even in comparative terms with Europe from 1530 to $1590 .^{19}$ As matter of fact historians agree that in both cases the demographic growth was particularly intensive until 1570 .

The same impression emerges when we turn from population to the main indicators of cereal production (Yun 2004, pp. 199-200, Graphs 4.1 to 4.4). Even when allowance is made for the purely approximate nature of these figures, it is clear that the 1500s continued the long phase of expansion begun during the previous century. Abundant references can be found to indicate the expansion of other products, such as wine and olive oil in both countries. ${ }^{20}$ Probably this dynamism was less noticeable in the case of sheep, for which our data is less solid and convincing, but the overall conclusion must be positive. ${ }^{21}$ In regard to the secondary and tertiary sectors, if inherently more difficult to measure, the figures provided on urban and industrial developments are highly indicative of commercial and industrial growth in the northern Meseta and Andalusia and even in Catalonia, Valencia, and the coastal areas of Portugal. ${ }^{22}$

As traditional historiography has underlined, there can be no doubt that, aside from the commercial development described above, this general economic expansion was made possible by an increase in agrarian production derived from the extension of cultivated lands, to which many contemporary sources allude. ${ }^{23}$ This is evident at a local level in the permissive policy of many towns and councils with regard to the breaking of

${ }^{19}$ The figures given for Spain by De Vries (1984) (6.8 and 8.1 million inhabitants in 1500 and 1600 , respectively) appear less trustworthy than those of Nadal (1984, p. 74). Spain witnessed the second largest growth in all of Europe after England (0.86). Portugal is also in the most dynamic group with a $0.6 \%$ of growth per year.

${ }^{20}$ In Valencia, Cáceres, and Catalonia, the data sets refer to overall production of cereals, wines, and other goods, which are representative of the majority of agrarian production (Yun 2004). For other regions, see Casey (1983, pp. 266-7), Ibáñez (1995, p. 244), Huetz de Lemps (1967), Ponsot (1986, XIX, see chart 4.6), Pérez and Lemeunier (1984, Graph. 1), and Latorre (1989).

${ }^{21}$ The number of livestock in the Mesta appears to have fallen noticeably from 1520 (Le Flem 1972), but it does not appear that this contraction could have been sharp enough to bring down the overall agrarian product. A number of cases confirm this thesis (Lemeunier (1977, p. 327), Halperin (1980, p. 25)). Moreover there are reasons for thinking that this reduction was compensated by higher levels of stationary livestock farming and shortdistance transhumance (Ruiz Martín 1990a).

${ }^{22}$ Bennassar (1983, pp. 324-28), Pulido (1993), Elliott (1963, p. 56), García Espuche (1998).

${ }^{23}$ See, for example, López-Salazar (1986, pp. 151-252). For Portugal, (Magalhães, 1997). 
new soils and the need to attract settlers by conceding fiscal exemptions and access to unfarmed land (Pérez and Lemeunier 1984, pp. 63, 66, 69-72; Yun 1987, pp. 120-3). But the extension of cultivated land is also evident in the fact that those regions where the population density was lower in 1530, such as New Castile, Asturias, Galicia, Murcia, Andalusia, the lower Mondego, the areas around Lisbon, Alentejo, and other zones, were generally those that made the greatest progress over the course of the century. Only the kingdom of Aragon fell outside of this paradigm, for the reasons outlined above.

If very difficult to measure, intense bursts of interregional migration stood at the heart of this dynamic. Notwithstanding its notable potential for growth, the north-western area of the peninsula appears to have been sending inhabitants to the Duero and Tagus valleys for much of the sixteenth century both in Portugal and Castile. ${ }^{24}$ At the same time, the northern Meseta was providing settlers for Extremadura, New Castile, Andalusia, and Murcia. This same pattern is also found in the eastern regions, where the kingdom of Aragon hardly grew despite its low initial population densities, although it clearly helped to feed the notable expansion of Catalonia, even if the principal factor in the growth of the principality was the arrival of French settlers, while the kingdom of Valencia attracted immigrants from France, Gascony, Aragon, and Castile. ${ }^{25}$

But does the extensive character of the agrarian system mean that it makes no sense to speak of a growth in per capita income and productivity in the sixteenth century? This is in fact the most common idea among economic historians, and there are even those who, like Cipolla (1976) or H. Kamen (1978), denied some decades ago not only the existence of economic development but also, implicitly, the idea of genuine growth.

There exists, however, a great deal of evidence that allow us to be more positive and even to support a more critical view of the image of an economie immobile, as Hoffman did for the case of France (1996). As I think I have proved (Yun 2004, pp. 211-4) by using estimates of different regions such as New Castile, Catalonia, and Andalusia, there are many reasons to

\footnotetext{
${ }^{24}$ See the case of the migration flows to Medina del Campo in Marcos (1978, p. 272).

${ }^{25}$ For Catalonia, see Nadal (1984, pp. 74-82). For Valencia, attention falls on the annual accumulative growth rates of $0.47 \%$, and it can be supposed that these would have been still greater in the first half of the century. Ardit proposes a general rate of growth between $0.51 \%$ and $0.82 \%$ between 1530 and 1580 (1994, vol. I, p. 19). See also Furió (1995, pp. 271-4).
} 
think that the agrarian output increased faster than the population at least until the 1570s (Yun 2004, p. 213). In other words, it is more than probable that total population growth in the kingdom fell beneath the expansion of production for several decades.

We are faced, therefore, with an unmistakable agrarian expansion, meaning an increase in the agrarian product 'per capita'. Beyond this, insofar as the primary sector generated a significant portion of the total product and was accompanied by a phase of industrial and commercial developments, it is clear that this trend represented a phase of real economic growth in all senses. For this reason, it should not be surprising that, at the end of the century, the indicators for the consumption of meat among the Spanish should be very close to those of areas of notable economic vitality, such as Italy. And if, regrettably, there are only a few studies on the material culture of the period, it is nonetheless clear that a certain increase of production of consumer or industrial goods aimed at the domestic market took place, above all among certain sectors of the better-off peasantry, a trend that corroborates the overall pattern of changes (Livi-Bacci 1988, pp. 144-5).

But the most reliable indicator of economic growth in pre-industrial societies is, without doubt, the coefficient of urbanization which, in effect, represents the proportion of the total population that does not live off agriculture. Growing urban population rates therefore unequivocally indicate the increasing productivity of the rural sector, which was able to feed a higher proportion of people living in towns. This form of growth is undeniable across Spain and Portugal. As Map 3.2 shows the urbanization rates in both countries and in Castile in particular were already quite high by 1550 (the figures for Castile correspond in fact to 1530). Furthermore, the urban population not only grew more quickly than the rural one but did so in eye-catching proportions. An analysis of the figures provided by Jan De Vries shows that in Spain the percentage of the population living in urban nuclei with more than 10,000 inhabitants passed from $6.1 \%$ in 1500 to $8.6 \%$ in 1550 and $11.4 \%$ in 1600 ; whereas the overall development of urban centres within Europe went from $5.6 \%$ to $6.3 \%$ and $7.6 \%$, respectively. This rhythm is even faster in Portugal, where, thanks in part to the expansion of Lisbon, the figures were of $3 \%, 11 \%$, and $14.1 \%$ of the population in centres of more than 10,000 inhabitants (De Vries 1984, p. 146, Table 3.7). If we take the centres with more than 5000 inhabitants in England, France, Holland, and Castile, we find that one of the areas where this portion of the population had most quickly grown is Castile (Table 3.3). It had risen from an index of 62 in 1530 to 100 in 1600 


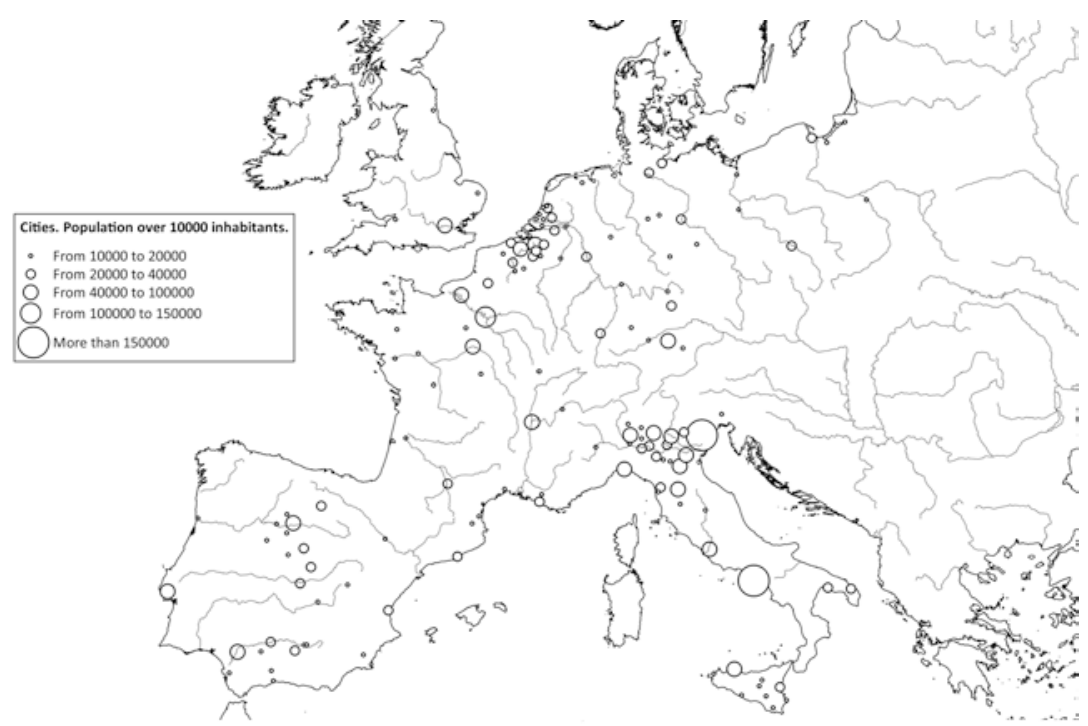

Map 3.2 European urban networks, 1550

Table 3.3 Urban population in Western Europe

\begin{tabular}{|c|c|c|c|c|c|c|c|c|}
\hline & \multicolumn{8}{|c|}{ (\% of inhabitants in centres of more than 5000) } \\
\hline & \multicolumn{2}{|c|}{ France } & \multicolumn{2}{|c|}{ England } & \multicolumn{2}{|c|}{ Holland } & \multicolumn{2}{|c|}{ Castile } \\
\hline & $\%$ & Index & $\%$ & Index & $\%$ & Index & $\%$ & Index \\
\hline 1500 & 9.1 & 105 & 5.3 & 66 & & & & \\
\hline 1530 & & & & & & & 13 & 62 \\
\hline 1550 & & & & & 20.8 & 72 & & \\
\hline 1600 & 8.7 & 100 & 8 & 100 & 29 & 100 & 21 & 100 \\
\hline 1650 & & & & & 37 & 128 & & \\
\hline 1700 & 10.9 & 125 & 17 & 213 & 39 & 134 & & \\
\hline
\end{tabular}

Sources: My own elaboration with data from Wrigley (1987) and Fortea (1995)

(1591 to be exact). Castile therefore exhibits, with England, the fastest rate of urban growth (Table 3.3). This urban development is even more meaningful if one considers that Castile, which represented more than the $80 \%$ of the Spanish population, was already by 1530 one of the more 
urbanized areas of Europe with 13\% of its inhabitants living in centres of more than 5000 people (more than in France or England) (see above Table 3.3). Likewise, by the same epoch, the $8.6 \%$ of the Portuguese lived in towns of more than 10,000, which is even more than in England and France too. It is not surprising that the most recent estimates of Spanish and Portuguese economic growth in terms of GDP per capita shed also a positive image (Álvarez Nogal and Prados de la Escosura 2013; Costa, Palma and Reis 2015). ${ }^{26}$

\section{The Advantages of Peasant Economies and Increasing Productivity}

What were the causes of this increase in per capita productivity that belie, at least in its most simplistic and absolute formulations, the argument for the economie immobile as well as the idea of an increasing pressure through rents that would swallow up any increase in production? ${ }^{27}$ Recent studies draw attention to the strictly relative nature of this immobility and provide reasons for thinking that interpretations such as those of G. Bois (1985) and R. H. Hilton (1985) that used to place emphasis on seigniorial extractions may need considerable modification. It may be worthwhile, therefore, to reconsider the peninsula's agriculture from the viewpoint of property rights and ensuing balance between land and labour. ${ }^{28}$

\footnotetext{
${ }^{26}$ Gelabert (1994, p. 184). The theme was set out and quantified by Prados de la Escosura and Álvarez Nogal after the first version of this idea had been developed in Yun (2004).

${ }^{27}$ The most complete vision is probably offered by Le Roy Ladurie, who coined the concept. See (1966, vol. I, pp. 226-35).

${ }^{28}$ It may seem strange to those scholars, such as North and Thomas, who have postulated a close correlation between individual property and agrarian growth (and, logically, by extension shared ownership and economic stagnation), but a more precise organization of the various ways by which soils were owned and a perfection of community practices was in fact positive in creating growth in the productivity levels of peasant labour. The theories of North and Thomas and their vision of Spain can be found in North (1981, p. 150). The passage above having been written for the first edition (Yun 2004), a number of colleagues have drawn my attention to parallels with the excellent work of Horden and Purcell (2000). Probably some parallels do exist. However, I would place emphasis on institutions and property rights and their interaction with connections between regions and their respective ecological systems. In any case, Horden and Purcell attempt to provide a very generic model of the Mediterranean (probably not unique and exclusive to the Mediterranean), while here I aim to study the specific key factors that allow us to define a particular phase of expansion on the sixteenth-century Iberian Peninsula.
} 
Everything indicates that the fixing of local by-laws (ordenanzas) of towns and villages in the fifteenth and early sixteenth centuries led to a greater balance and complementarity between agriculture and livestock breeding and, above all, extended the advantages of this equilibrium to ever-greater surface spaces. Many measures were introduced to clarify not only property rights but also the use of the land, with the aim of attaining greater security in farming: the clearer demarcation of spaces over the seasons within the municipal estates, the appointment of guards to watch the vines and livestock, the creation of institutions such as the town shepherd, and other similar measures. In many cases, these initiatives were successful, with communal fields being used to benefit both agriculture and pastoralism at different times in the agrarian calendar, given the different potential uses of soils and the ecological conditions of each unit or area. ${ }^{29}$ Rural communities not only improved the productive conditions of their estates but also, from the fifteenth century onwards, were keen to forge agreements and accords with other communities. The resulting sharing of pastures among councils, frequent in the Castilian Meseta, allowed cycles of transhumance between different municipal areas, as well as the short-distance displacement of livestock and general co-ordination of the demands of cattle rising with those of agriculture. Moreover landowners themselves were keen to implement this type of improvement, thus achieving a greater balance and complementarity between different agricultural zones which, without doubt, would contribute to heightening overall productivity. ${ }^{30}$ In some areas the community coordinated the use of resources that were inherently difficult to regulate without collective oversight, such as water; in some areas of Aragon, the Spanish Levante, and the Portuguese banks of the Tagus River, the community would even undertake to dig and maintain

${ }^{29}$ The positive effects of greater security and the reduction of risks through measures of this sort with regard to crops were especially important for the extension of vineyards and other arboreal products. These were always highly vulnerable to the destructive incursion of livestock, above all at moments of flowering and fructification of the plant which, moreover, required significant investment, sometimes over several years, in work and care. See the case of the Tierra de Campos in Yun (1987).

${ }^{30}$ This long phase of productive expansion contemplated the increase in Castilian and Aragonese livestock, which would be directed towards the zones of poorer soils, Murcia and Valencia (Lemeunier 1977, pp. 338-9; Ardit 1994, pp. 56-7). In Aragon local- and interregional-level cycles of transhumance developed under the auspices of the landlords, which increased the complementarity of resources between the highlands of Teruel or the lands of Tierra del Moncayo, Pyrenees, and the banks of the Ebro river (Abadía 1993). 
irrigation ditches. ${ }^{31}$ In many regions, from Malaga to Mallorca and Valencia to Lisbon or Cáceres, the municipal by-laws prompted and regulated the expansion of fruit and mulberry trees in combination with other forms of activity and in harmony with the cycles of agricultural farming. ${ }^{32}$ This complementary balance in exploiting resources was also found in the trend towards the specialization of products on the local level. In the Duero Valley, areas such as the Tierra de Medina, to the south of Valladolid, took steps towards specializing in viticulture, while the nearby area around Tierra de Campos began to focus on cereal production. This complementarity was determined not so much by the connections between these regions as by the effects of the growth of Valladolid, equidistant between both regions, due to its different ecological and institutional conditions. Similar movements were found in the Rioja region or in Murcia (Pérez and Lemeunier 1984, pp. 69, 78-9). Indeed, these regions were not so different from many areas around Lisbon where complementarity led to more interregional trends: here the chance to import cheap wheat over several decades allowed for the extension of the vine and other products in the regional hinterland.

All of this brought about a more efficient and secure use of the land. It also led to a greater efficiency in the use of labour and in the balance between soil and labour. In fact, this equilibrium adapted to the different agrarian cycles throughout the year and, by mobilizing hands at times previously marked by relative idleness, forged a more efficient work cycle over the year. ${ }^{33}$

${ }^{31}$ Apart from the examples cited above, see those for Valencia in Peris $(1989$, p. 255$)$ and Murcia in Pérez and Lemeunier (1984, p. 84) or the form by which Morisco agricultural techniques were blended into the systems of Christian communities, bringing about notable advances in Ponsot (1986).

${ }^{32}$ See the surprising case of Cáceres, where the ordenanzas or by-laws brought about the expansion of mulberry tree groves and fruit trees (Pereira 1991, pp. 128-32). On the development of this type of products in Portugal, very much connected to what Thirsk called alternative agriculture, see Magalhães (1997, pp. 234-9).

${ }^{33}$ The example of the peasants of Murcia is illustrative in this regard. They cared for the vines in March and collected the leaves of mulberry trees so that between April and June, the silkworms could feed on them while the labourers were cutting the barley and leaving it to dry between June and July. Wheat was then also harvested. Some could even work in the salt farms from May to September and in the trap nets in June and September; from the latter month, it was possible to sell some products in local fairs, before harvesting the wine in 
The intensification of work patterns in combination with the agrarian cycles was often accompanied by the interregional migration of temporary workers. The peasants of the north of the peninsula, highlanders, Galicians, and Asturians were increasingly present in the Castilian Meseta during the harvest weeks, after which they gradually made their way back towards their homes in a rhythm set by the ripening wheat, taking employment in each region for a few weeks at a time as they steadily moved northwards. Of course some labourers did remain in the Duero Valley for the grape and olive harvests in September and, after this, to work as peddlers and in the transport of goods to their homelands, carrying with them a variety of products acquired or commissioned in Castile's summer fairs (Vassberg 1996, pp. 67-77). Equally important were the short-distance movements, such as those of the settlers of the Castilian Extremadura who went down to harvest olives in Seville and of the people of La Mancha who farmed their lands during nearly the entire year but descended upon Murcia between April and June to farm the silkworms and harvest the wheat. ${ }^{34}$

The permanent migration of people indicated the existence of a surplus workforce and, therefore, a decreasing marginal productivity in the zones of the north of the Central System (both in Portugal and in Castile), in France, or in upper Aragon; labour moved from these areas to ones where high-quality soils could be farmed and, consequently, where labour's marginal productivity was higher. The result of a reallocation of this sort between land and labour could only be an overall increase in productivity per person. ${ }^{35}$

Despite there being very few incentives for investment for many landlords, there were some improvements in fixed capital and agrarian techniques. As we have seen, in Galicia and Mallorca, the tendency among proprietors was to rent lands as units of production with everything necessary

October. From this point to the end of the year, the cereal fields could be prepared, but, in addition, in December and January, the olive harvest had to be collected. Peasants might still be involved in the storage of olives or the shovelling of snow. See Pérez and Lemeunier (1984, p. 89).

${ }^{34}$ Herrera (1980, p. 232), Pérez and Lemeunier (1984, p. 90).

${ }^{35}$ This is more important if we take into account that in many areas of the South, which had low densities in the first half of the century, there must still have been an abundance of good lands which had yet to be farmed. 
on them, something which shows an interest in agrarian equipment as the base for cultivation. As we have seen, in Catalonia the masia, whose basic construction represented the investment of fixed capital, was emerging as a productive unit in which the weight of the buildings, installations, and means of production increased, thus sparking a concomitant proportional improvement in peasant labour productivity. In Andalusia they were now building small cottages in the fields where the journeymen could spend the night in order to save time by avoiding long-distance displacements during periods of work (the sewing and harvest of olives and grapes), thus allowing the farming of lands which were not necessarily poorer but, more simply, had gone unused for centuries. The cortijos not only offered the necessary buildings, stables, or areas of temporary lodgings for the seasonal workers but also increased the number of mills for cereal and olive oil production in proportion to the expansion of olive farming (Herrera 1980, p. 232; Elliott 1963 , p. 30).

There were technical advances in farming that, despite their relatively limited impact, should not be dismissed entirely. These improvements represented modest, but accumulative, advances. As we have seen, in Galicia and Asturias, a sort of pre-revolution of maize was brought about by millet. If the cultivation of millet had relatively modest beginnings in Spanish Galicia, its introduction into many regions of Portugal would be extensive and important. In the humid areas of the Atlantic North, the new species of African maize were really successful, in part due to the endemic scarcity of wheat, which was more apt for the plateau of the South, while rye was extended in the hills of the interior (Magalhães 1997 , p. 231 and ff.). The spread of new crops such as sugar, rice, and the mulberry tree in many areas of Valencia, Aragon, or Granada and Malaga represented a decisive step forward that, moreover, often took place in the gaps between farmed fields and could be combined with other crops in the irrigated meadows as a form of alternative agriculture. In Murcia some of these small advances-significant due to their accumulative effect - ran from improvements in the measurement systems to the diffusion of waterwheels as a method of raising water in the irrigation ditches (Pérez and Lemeunier 1984, p. 65). And, if the effects of these improvements were most spectacular in the irrigated zones, there was no shortage of progress in the dry lands, manifested, for example, in the system of 'pasture and crop' and in the progress made in the enclosure of pastureland and use of fallow in combination with cereal cropping 
and the winter grazing of livestock in oakland (adehesamientos). ${ }^{36}$ This system had a parallel in the combination of olive and cereal cultivation in some zones of Coimbra (Magalhães 1997, p. 245). Of course, specific forms of property and seigniorial rent were sometimes behind these advances. As said above, while a good deal of landlord revenue was not usually ploughed back into productive investment, in the context of a growing population and demographic mobility, it often created the institutional conditions that allowed peasant initiatives to have free reign. Some of these improvements-above all those implemented in lands rented out as enfiteusis for a lifetime or in perpetuity-were tied to the interests of the peasant to optimize the productivity of soils over which he enjoyed complete control. There were also forms of renting land, such as letting in return for a proportion of the products (share cropping), which created a positive stimulus towards improvement in some areas of the peninsula, specifically when guarantees were given that the landlord's portion or share would not be increased (Miranda 2017). In some areas the growth of seigniorial income could be achieved by rolling out new crops or using new technology. One example of this was the duke of Gandía's interest in expanding the growth of sugar cane and installing trapiches, mills to grind it, in his estates; many other landowners were keen to produce silk. And, of course, in all estates there was a clear movement towards the repopulation of the land, something which lay behind the productive enhancements of the century.

As agrarian historians have often remarked, the substitution of oxen for mules in some areas reduced the soil yields but was compensated by a resultant increase in the level of human productivity per hour worked. In many regions overall factor productivity must have increased until the top

\footnotetext{
${ }^{36}$ For example, in many regions of southern Spain, the system of 'pasture and crops' was extended, generally in the 'mountains of holm oaks', (monte hueco de encinas), meaning on one surface or area, a number of different forms of farming were undertaken, ranging from grazing lands to cereals, thus generating a wide range of products-woods, firewood, acorns, and so on (Pereira 1991, p. 99). In Salamanca, Extremadura, and Andalusia, examples of creating enclosed pasture (adehesamiento) have been found, which do not necessarily mean the displacement of cereal by livestock. On the contrary, it probably represented a more efficient form of combining both practices within large estates reserved for communal use and in which integrated systems for the use of soils were in place, 'to the great improvement of the ecological components of some zones' (Valle 1985, pp. 536-8).
} 
earth was finally exhausted. The development of complementary activities outside of agriculture entailed the mobilization of otherwise idle hands. This resulted in the expanding use of female and male labours. David Vassberg has written that 'many peasants, especially those resident in the mountains, spent two or three months a year as itinerant merchants, or as muleteers or transporters, earning extra money'. Certain towns and areas of course played a prominent role in these networks, above all those situated in or near the frontier mountain ranges that separated these natural regions ${ }^{37}$ Equally important was the development of activities to transform agrarian products. The production of charcoal from wood was common from the meadows of the south to the mountain economies further north. But in some zones, it became a decisive activity, as was the case in the Basque Country and Navarre. For some of these peasants (above all those of the Basque Country), agrarian pursuits and the commercial exploitation of the mountain were combined with involvement in the iron industry (Bilbao 1987). For similar reasons, the development of this type of activity was also clear in Catalonia: 'forges and mills multiplied in the sixteenth century along the banks of the rivers and mountain streams' (Vilar 1962, vol. I, p. 545). Above all else this increase in peasant multiactivity was important in producing textiles and in manufacturing clay objects and leather goods and a multitude of other niche crafts. In many towns the production and sale of wool textiles, straps, farming tools, leather, clay, and linen products developed apace. And in some areas, such as the Rioja region, Segovia, Córdoba, the Algarve, Beira, between the Duero and the Portuguese side of the Miño region, and many others, the development of the domestic textile industry had the same effect of mobilizing unemployed workers, while something similar occurred in many Morisco areas of Aragon and Castile. ${ }^{38}$

The more pessimistic models and interpretations cannot be supported either by the available data on the evolution of rents or seigniorial demands. Certainly, the extension of the farmed area and pressure on land entailed

\footnotetext{
${ }^{37}$ Vassberg (1986, p. 3), Ortega (1974), Salomon (1982), and da Silva (1967). On the role of the Moriscos in transport activities and commercialization, see Halperin (1980, p. 73 ).

${ }^{38}$ Brumont (1993, pp. 135-6), da Silva (1967, pp. 29-31, 112), Fortea (1981, pp. 281-8). In the Morisco communities of Valencia, 'entire villages' of the duke of Gandía were employed in sugar cane cutting and the mills dedicated to its grinding, in making esparto and linen products, shoes, and mats (Halperin 1980, pp. 66, 70-1). For the Portuguese regions, see Magalhães (1997, pp. 254 and ff.).
} 
an increase in payments for the use of the soil. But this process was thoroughly shaped and delayed by forms of ownership and property rights that, as we saw in Chap. 1, were directed at the building up of the seigniorial estate's population and the development of peasant economies.

In Galicia, Castile, Valencia, Catalonia, and other areas, the extensive properties let out in enfiteusis to families or communities created relatively secure conditions for their exploitation. The fact that they paid fixed (and predictable) sums for the use of the land encouraged peasants to take advantage of productive improvements. Even when the lands were given on short-term or revisable leases, the terms of contracts included fixed clauses or conditions of considerable importance: one such accord from Andalusia relaxed the rent payment in case of natural catastrophes. Frequently lands were exploited over long periods by tenants belonging to one family group, with successive generations forging a personal relationship with the proprietor; for his part the landowner gained additional security in rent payments, a trade-off which tended to lessen the tendency to increase these demands. In this way the restriction of the number of potential tenants to the inhabitants of a small town or village limited the possibility of raising land rents (Lemeunier 1998; Sebastián 1999, pp. 335-6). This and other similar forms of behaviour appear to have been especially important in the renting out of meadows and large properties for payment in coin, something which explains the barely noticeable increase in rents paid and even their diminution in real terms (Yun 2004; Miranda 2017). The abundance of unused lands (baldios) or council lands (tierras concejiles) for which either no or very low rents had to be paid had a similar effect. And, on top of this, the first 40 years of the century witnessed a marked effort to extend communal rights on the royal estates, with the implicit permission of the Crown.

Of course, mechanisms existed for the adjustment of land rents. From the end of the fifteenth century, landowners began to take an interest in revising the foros and censos entifenticos sometimes in perpetuity, hoping to rent lands on short-term, revisable contracts and in return for direct payment in specie. It is also clear that many nobles and powerful estate owners were tempted to claim royal lands where doubt existed over proprietorship, and this trend clearly reduced the ability of small holders to expand their farms without renting. But this land grab not only allowed for a period of readjustment but was also at times difficult to accomplish. Contrary to what was occurring in other areas of Europe (e.g. those zones of England where claims of full ownership were being advanced to change the terms of leases), many peninsular landlords had to face not simply isolated peasant 
families or small alliances of them but entire communities. In cases of this sort, peasant settlements not only resisted the ambitions of their lord by force but also-and before arriving at this extreme solution-enjoyed a notable capacity to recur to the royal law courts (the cases in the archives of Chancelleries are indicative of this facility; see Chap. 5), a practice that generated considerable additional cost to the landlord and served as a reminder of the value of prudence before entering into such costly lawsuits. The idea was that the justice system should maintain the laws of the kingdom, and it, in conjunction with the health and resilience of the municipal estates, played in favour of many communities over long periods.

Even for those owners of lands ceded in enfiteusis (these were very often nobles and ecclesiastical institutions), there was not always much sense in compelling the peasants to revise rents which, aside from not being easily modified, were tied to other more important forms of income, such as the tercias, alcabalas, and others. If we take into account that many noble families could overcome their income deficits through favourable credit arrangements in the form of censos consignativos (mortgages endorsed by their mayorazgos - Chap. 4), it is easy to understand why, despite the structural tendency to revise land property rights, there were also considerable practical reasons mitigating against any such alteration.

The results of these developments were widely evident. Even in areas of strong demographic pressure-such as in the Tierra de Santiago or Jaénit was sometimes the case that the available rise in the revisable rents on lands was not automatically applied by landlords. ${ }^{39}$ Moreover some of these mechanisms could, in the final instance, be beneficial for quite a few of the farmers. This was because the increase in rents and the pressure of demand upon lower-quality lands, together with the increasing money supply, brought about a rise in prices which in the end benefited the more efficient farms and those that were less exposed to this type of burden. Certainly, the inflation of the sixteenth century should not be explained in these rather Ricardian terms; nor were prices the most important variables in peasant incomes. But many farmers with surpluses which were not subject to higher rents were able to obtain this benefit through the market. It

\footnotetext{
${ }^{39}$ Yun (2004). It should be noted how, in the cases cited, the variable remained almost static until at least 1540. Overall, within this expansive tendency set out according to theoretical formulations, the trend of this form of extraction on produce should have been stable until the early sixteenth century.
} 
is, moreover, evident that the effects of this change, if marginal, increased over the course of the century.

In this way, the fixed nature of seigniorial land rents created better conditions for peasant businesses for several decades, while the increase in the productivity of work over a long period compensated for any rise in payments to landlords. The combination of factors was favourable for economic growth and even for an increase in the levels of productivity. However, the theme should also be approached with an eye on other forms of extraction levelled on production, such as the fiscal burden. To understand this fully, a more general perspective is needed.

\section{The Final Test: Industrial Development and Regional Urban Systems}

The final and perhaps the most decisive proof of the consistence of the sixteenth-century Iberian economic expansion-that is, of its non-semiperipheral character and of the strength of its agrarian and general domestic forces-can be found in the evolution of the changes taking place in the industrial sector and the regional urban networks. Though some ideas have already been advanced (Chap. 3), these aspects deserve additional reflection.

The textile industry, which was to be the most affected by the importation of foreign goods, underwent changes and introduced productive improvements which were intended to allow it to adapt to demands for higher-quality goods and that were characteristics of a vigorous and dynamic process of import substitution. In Cuenca, for example, we know of the dissemination of the verlagssystem and the merchant-manufacturers who came to 'put workshops in their homes'. Enjoying annual profits that averaged $15 \%$ in 1553 , this sector had, since the end of the previous century, been adopting itself to the 'new draperies' (Iradiel 1974, pp. 232-3; Reher 1990, pp. 27, 30). Córdoba also overcame the sector's purely artisanal structure in order to facilitate the development of the 'new draperies' and the products' adaptation to the ever-changing demands of a market of greater dimensions and quality (Fortea 1981, pp. 271-2). This development was possible thanks to the introduction of agro-urban production circuits (Fortea 1981, pp. 279-80). A process of this sort also led to significant progress in the silk industry. A number of factors were behind it: the greater availability of raw materials, easier access to dyes, and improvements in the workforce, largely as a result of the efforts of the Moriscos (Fortea 1981; Aranda 1984). 
In Segovia the growing weight of a new type of merchant acting as a verlaguer was significant. The result would be an increase in the quality and the wider dispersion of light cloths, which were even adapted to American demands (García Sanz 1987; Lorenzo 1979, p. 435). The verlagssystem, based upon an agrarian-urban cycle, developed in Toledo, advancing both the woollen cloth and silk industries. The wool industry also developed in the hinterland zones of Portugal, near the great livestock tracks. But the most dynamic sector was perhaps the one that produced cloth and linen fabrics, tied to domestic consumption but also-importantly-to the production of naval canvas (Costa 1997, pp. 253-81). Across the entire peninsula, a trend towards the production of high-quality items (and even the imitation of foreign fashions) can also be discerned, particularly in the silk industry. This was possible thanks to access to dyes and colourants through the international commercial circuits. Something similar happened in Valencia, whose production was strongly linked to demand in Castile ('the main customer for Valencian silk fabrics'), or in Barcelona, where the weight of the artisan sector grew thanks largely to domestic demand. ${ }^{40}$

We do not have in-depth studies of the functioning of the guilds, but everything indicates that, at least during the first half of the century, these would have been more open than has sometimes been believed. Where it has been possible to make accurate measurements, such as in Valladolid, it has been found that only $30 \%$ of apprentices came from the city itself (Bennassar 1983, pp. 217-21) — and it can be assumed that of these only a fraction came from the families of the masters who did the hiring. Despite later problems, many sectors displayed a certain permissiveness with regard to the activities of the Morisco population, whose technical expertise was of great importance in areas such as the production of silk fabrics (Aranda 1984). Thus, some sectors at least responded positively to some of the variables that elicited such pessimism from Ogilvie (2011), who has been highly sceptical of the capacity of Old Regime guilds to introduce productive improvements.

A comparison of the textile production figures for a number of Castilian cities against those of their most active rivals in Italy is very meaningful. This is especially true in light of the former's low points of departure. If, by 1560 , 20,000 pieces of cloth were produced in Venice, Córdoba reached the

\footnotetext{
${ }^{40}$ Montemayor (1996, pp. 201-33), Casey (1983, pp. 88-90), and Vilar (1962, vol. I).
} 
figure of 18,000 , to which might be added the 7000 of the surrounding areas, while in Segovia some 16,000 were manufactured. It must, of course, be added that these figures can only take us so far and that the great Italian centres of production in Venice and Tuscany definitely produced goods of a higher quality and, therefore, of higher monetary value.

Moreover, the development of other industries should also be noted. This is true, for example, for the construction industry and associated sectors. Behind its dynamism there was the growth of population, the main roots of which are to be found in the expansion of the primary sector. But also significant was the new conception of the home and the spread among elites of tastes and lifestyles imported from abroad and, above all, from Flanders and Italy (Yun 1999c). By the 1540s the notion of the 'nobility of a city' had clearly won many minds and hearts, becoming an increasingly important facet of the political culture of the time and manifested in the people and buildings and memorable things that there are in a place, with temples, hospitals, bridges, castles, public buildings and private homes'. ${ }^{41}$ The result was the development of a range of industries related to construction, including metalwork and carpentry. ${ }^{42}$ The fact that construction developed in productive circuits restricted and closed in on themselves helps us to understand the huge impact of this sector on the domestic and local economies.

This change in the habits of consumption, coming on top of demand for cheaper, less sophisticated goods, also lay behind the expansion of the goldsmith (from candlesticks to cutlery), leather, and embossed-leather trades, the latter two being important in Córdoba (Fortea 1981, p. 243). New eating habits, which encouraged the use of cutlery and tableware, gave impetus to the porcelain industries of Talavera de la Reina or Triana (Seville), while more popular tastes encouraged the clay furnaces that sprang up in many villages and cities across Spain (Sánchez 1989, vol. I, p. 151). Toledo also boasted industries dedicated to silverware and jewellery (also extremely important in Córdoba) and the production of swords, musical instruments, sculpture, and painting. Demand for these artistic products often came from churches and clergymen (Montemayor 1996, pp. 201-6).

${ }^{41}$ Diálogo en Alabanza de Valladolid, en Alonso Cortés (1955, p. 250).

${ }^{42}$ See the importance of these sectors in Medina del Campo (Marcos 1978, pp. 312-20), Cordoba (Fortea 1981, p. 243), or Seville (Bernal et al. 1978). 
This development was not confined to industry. Progress was achieved in mining thanks to technical advances of the first magnitude, linked both to government and private demands. The demands generated by trade, the army, construction, the textile, leather, food, and paper industries - all of these sectors fed a remarkable drive to farm unused fields; to advance the mining of iron, copper, tin, sulphur, and lead; to make better use of forests; and to produce dyes, lime, plaster, and brick (Sánchez 1989, vol. I, pp. 119-65).

Mining was a productive branch also tied to one of the most dynamic sectors-naval construction. And the development of this activity was undeniable. It would expand significantly in the north of the peninsula, in certain areas of Catalonia, and, above all, in Seville and Lisbon.

These observations explain why, in spite of the development of the export economy, urban growth did not conform in any way to patterns deemed typical of 'peripheral economies', which are generally taken to have low rates of urbanization, with the major centres found in the geographical periphery of the country. Regarding urbanization rates, we have already shown that they were high. But what about the regional distribution? Though one cannot speak of a peninsula urban system - that is, one stretching across Iberia-but rather of regional systems, the great dynamism of the hinterland is very meaningful. Areas of coastal development existed since the fifteenth century (Chap. 1), such as the shoreline from Barcelona to Valencia and Murcia/Cartagena. Seville provides another example of an expansive city, being tied to maritime activities for commercial exchange. Furthermore, the growth of the Portuguese cities from Lisbon to Porto (including those of the lower Tagus near the capital) was certainly very notable (Costa 1997). But the Iberian urban networks were more complex.

As regards Portugal (Table 3.4), around 1527 the number of Portuguese centres that passed 5000 inhabitants was very small when compared with Castile and the urban pattern, with the fast growth of Lisbon, reminds that of a peripheral economy. ${ }^{43}$ On the one side, Portugal's cities' growth

${ }^{43}$ The great difference, however, was in the very physiognomy of the urban network. The gap between Lisbon and the rest of the country was not only greater-for example, in comparison with the difference between Seville and the rest of Castile-but also grew during the century. It would be necessary to wait until 1600 - with the boom of Madrid-to encounter a similar breach or imbalance in Castile. In 1527 Lisbon already boasted 55-65,000 inhabitants and was the most populous city on the peninsula (Seville had hardly reached 50,000 ). In 1550, Lisbon may have reached 100,000. Porto had fewer, 13,000; by the midpoint of the century, this number had risen to 15,000 (Disney 2009, vol. I, p. 145). 
Table 3.4 Urban population in Portugal, c. 1530

\begin{tabular}{|c|c|c|c|}
\hline & \multicolumn{3}{|c|}{1530} \\
\hline & Moradores & Inhabitants & $\%$ urb. pop/tot. pop \\
\hline Lisbon & 13,010 & 55,943 & \\
\hline Porto & 3006 & 12,926 & \\
\hline Evora & 2813 & 12,096 & \\
\hline Santarem & 1988 & 8548 & \\
\hline Elvas & 1916 & 8239 & \\
\hline Tavira & 1547 & 6652 & \\
\hline Guimaraes & 1405 & 6042 & \\
\hline Coimbra & 1329 & 5715 & \\
\hline Lagos & 1310 & 5633 & \\
\hline Portalegre & 1224 & 5263 & \\
\hline Setubal & 1220 & 5246 & \\
\hline Total urban pop. & & 132,302 & 11 \\
\hline Total population & & $1,200,000$ & \\
\hline
\end{tabular}

N. B. towns with more than 5000 inhabitants

Sources: Teresa Ferreira Rodriguez (1997,p. 185) and Miranda (2016), using the coefficient 1:4.3 for the ratio morador/inhabitants

was based upon long-distance relations. Lisbon-and more and more Porto-was involved commercially with the fairs of Castile, with Seville, Flanders (highly significant), and, above all, Antwerp. They had also growing commercial connections with the African coasts, Asia, and Brazil. The dynamism of these cities was based upon their role in the process of reexporting goods, as well as upon the arrival of wheat from North Africa: for the entire century, Lisbon became the redistribution centre of the country at times of dearth. But, on the other side, the oceanic expansion allowed cities such as Lisbon and Porto to have a marked impact upon their respective hinterlands, in which they would generate growth. The series of city ports that dotted the lower Tagus and, to a lesser extent, the Duero were further proof of positive effects of Lisbon and Porto on nearby centres, as was the growth of settlements on the Atlantic seaboard and as of towns of the interior such as Portalegre, Evora and Elvas, connected to the trade with Castile (Table 3.4 and Magalhães 1997, pp. 206 and ff.). Hence, this urban network, while, indeed, coastal and very much dependent of international trade, was not necessarily proof of a dependent economy as it is defined today. 
In Spain the most dynamic towns remained those of the interior of Castile. The high degree of urbanization of the Crown of Castile and particularly of Extremadura, the Upper Guadalquivir Valley, New Castile, and Old Castile, in 1600 is very visible in Maps 3.2 and 8.1. That same impression emerges from an analysis of the active population of some of the Castilian cities already mentioned, among which the primary sector hardly reaches $20 \%$ of the active population and craftsmen are always above $50 \%$ of the total (Yun 2004, pp. 170-2). Particularly in the Duero Valley, these were mostly urban centres in the interior of the country, where the percentage of inhabitants working in industry and services was very high.

In conclusion, market integration and the dynamism of the agrarian and industrial sectors had not led to the formation of a pan-Iberian urban network. Rather, there had emerged a series of regional urban systems tied to the development of the exterior sector-and not always due to dependency relations - as well as an urban network in the centre of the Crown of Castile with degree of dynamism comparable to that of the most developed zones of Europe. Thus, there emerges the question: how can the economic and institutional model that stood behind this situation be characterized?

\section{Patterns of Economic Growth, Market, AND INSTITUTIONS}

The answer to this question is complex: rather than an economic model, it involves regional models that developed links among themselves. Growth was largely based upon regional dynamics and was also made possible by the connections of each of these regional ecosystems to the outside world. The structure of these regional economies had not changed substantively in regard to the situation established in the fifteenth century (Chap. 1). On the Mediterranean front, however, Barcelona had reacted to Valencia's stealing a march; the Atlantic economy was now bound together more forcefully around Lisbon and Seville; the corridor joining the Basque towns to Burgos and the Duero Valley was also strengthened. The zones of the hinterland, which had been the most powerful motor for growth, were centred on the area from Duero Valley to Toledo, sometimes extending their ties towards the southern Meseta and even Andalusia (Ringrose 1983b). 
The key was the existence of regional economies that did not constitute a completely integrated interior market but nevertheless created enough synergies among themselves to push forward growth. This development was the fruit of their more thorough insertion into international and even global economic circuits, as well as of a number of additional factors: a more efficient agriculture, the existence of complementary elements in the use of factors such as labour (with both definitive and seasonal emigrations providing positive stimuli), the synchronization of crops, the growing commercialization of the peasant production (very dependent upon the density of the urban networks), the complementary and connected nature of the ecological systems, and organization and technical improvements in the productive process.

In these circumstances, property rights that were very much at odds with those considered optimal by the theorists of the new institutional economics, in combination with moderate levels of land rent pressure on peasants, in fact had positive effects. All of these factors coincided (and dovetailed) with a very moderate level of fiscal pressure, a variable which, if inherently difficult to measure on account of the enormous disparity between actual and theoretical rates of taxation, appears to have evolved below real-term values for several decades, judging by the trend of the most important exactions. This occurred (see Chap. 4) in the Crowns of Portugal, Aragon, and Castile, above all from 1530 until 1560-1570. With regard to the latter period, where taxes increased noticeably in the course of the century, it is important to note that they hardly increased in real terms. But this was also the case of the sisas of Portugal, where fiscal pressure swiftly led to customs and duties being levied on foreign trade. Taking into account the upward evolution of agrarian production and population, it is obvious that the relative fiscal burden of the state on economic activities in general, and agrarian activities in particular, fell until at least $1570 .^{44}$

So, if at some point during the first half of the century-very possibly in the first 30 years of it - some burdens were increased, then it is certain that this change could have had only a limited impact upon the overall expansive trend. These years were marked by an abundance of lands and labour mobility, with growing productivity in levels of both agricultural work and

\footnotetext{
${ }^{44}$ See the case of Córdoba in Fortea (1986, p. 76); for more general estimates, see also Bilbao (1987).
} 
land productivity, and successful resistance to any increase in seigniorial rents; they also witnessed a burgeoning array of auxiliary peasant activities, marked urban expansion, and even some degree of specialization in the role of the cities, with a balance of commerce that had yet to be destroyed by the massive importation of high-quality industrial products. If, from the 1530 s, land rents began to lose part of their rigidity, this was a slow process offset-above all in Castile-by a lower burden in real terms of other types of impositions, both in the countryside and in the city.

This pattern of economic growth logically suffered from blockages: yet, by the same standard, it grew to historically unprecedented proportions. Nothing similar would occur again in inland Spain and Portugal until the nineteenth century. As a matter of fact, viewed in perspective, this phase of growth reached rates (understood in terms of product per capita) that were close to those achieved in some areas of nineteenth-century Spain and Portugal (Álvarez Nogal and Prados de la Escosura 2013; Costa, Palma and Reis 2015).

Looking at this development, some historians have written of a 'failed transition' to capitalism (Casey 1985); others have postulated an agrarian capitalism-a dubious term in my opinion-in regions such as Andalusia. Moreover, the notable development of the market makes it tempting to consider it a central element in the working of the economy. A more detailed analysis of the institutional framework demonstrates, however, that the political economy behind this process corresponded to institutional systems that are normally considered very inefficient for economic growth within the schemes and paradigms of the new institutional economics (more on it in Chap. 5).

One of the best signals or indicators of this argument is found in the fact that an important part of the incomes of the seigniorial class and the great ecclesiastical institutions came through taxes rooted in privilege and coercion and not in the direct commercialization of the landlords production. In this situation there were stimuli for productive improvements but the limits of the system would depend on to what extent there was a radical change in the institutional framework.

As regards peasant economies, a number of families' distribution of work over the year were affected by the market, and their sale of commodities and labour increased. Hence, the market augmented and diversified the incomes of many families, contributed to the division of work, and, to a certain extent, encouraged a form of specialization not entirely unrelated to economic growth. Yet, in comparison to today's capitalist economies, 
the market was highly limited as a mechanism for the assignation of productive resources. In other words, the market was a very important force, but its impact upon the family economies and on the productive specialization and on the combination among land, labour, and technology will remain relatively small in comparison to what happens in our current economies.

The cities themselves were, in spite of their commercial and industrial development, units of jurisdiction, genuine urban seigniorial estates. Their status and character affected not only the lands under their control but also the organization of industrial and commercial activities in them, which were strongly regulated by criteria far from the optimization of the efficiency of productive factors and closer to those of reciprocity and social assistance given to the guilds and confraternities (Chap. 5). These criteria even affected the specialization of functions in the cities, which, by their very nature, had to be limited, because, in effect, urban jurisdiction and the capacity for enforcement that it gave the cities implied the establishment of limits to commercial activities and products from other centres, something which, obviously, limited the transfer of goods and services between them and, consequently, the productive specialization inherent in all urban systems in the strictest sense of the word. It was logical that in many zones, and in the heart of Castile, above all, cities were highly developed, as they constituted nuclei that concentrated land incomes and a diversified demand for goods and services that could only be met by the development of the tertiary and secondary sectors. Some of these cities therefore produced goods and services that could be exchanged beyond their jurisdictional frontiers, giving rise to a certain form of specialization.

This was not an economy where institutions and property rights led to higher levels of economic efficiency in the way new institutional economics postulates. It could even be said that, from this perspective, it is odd that such a significant period of expansion had taken place. But the remarkable phase of expansion-remarkable, that is, on the scale of pre-industrial economies-has an explanation.

This explanation must be found in the fact that the institutions' efficiency did not depend upon their apparent similarity to those of advanced capitalism but rather upon how they operated in specific historical contexts and, above all, upon the availability of resources whose assignment they regulated. In other words, the efficiency of institutions resided not in 
the fact that they were good or bad per se but in the way in which they positively combined with ecological factors and external changes tied to international commerce. The Iberian sixteenth century economic growth shows the role of the village communities and their forms of organizing agrarian systems and commercial circuits were positive in a world in which the availability of land and other natural resources was high and the possibilities of combining labour, migrations, agrarian seasonal complementarities, space, and commercialization were many. In this context, exclusive and very precise property rights (those that reserved all rights upon the use of land to individual proprietors) were not indispensable, as some visions derived from the new institutional history have presumed (North and Thomas 1973). Even communal properties, when combined with the regulation of the concejos or when in a scenario of land abundance, had positive effects for agrarian expansion.

It is even possible to argue that economic growth was only possible because of the inability of some institutions (the councils, towns, and landlord, above all) to control population movements and interior migrations, two forces that contributed to the reallocation of land and labour in order to generate greater productivity. Behind everything lay the conditions set by regional ecological systems that allowed both long- and short-term emigrations to the south. Agrarian institutions were incapable of controlling and absorbing all of the wealth generated by the marginal activities such as the domestic production of manufactures and alternative agriculture. Equally, it should not be forgotten that if in theory landlords controlled the use of violence, then they had to exercise this right with moderation in areas where they encountered solid agrarian communities and where the development of royal justice balanced the scope for abuse by the mighty. The result was highly irregular, with numerous local and regional variations. The difference, for example, between the areas of the Crowns of Castile and Aragon, or even between regions such as the Ebro Valley and the fertile regions of Valencia (areas characterized by very different forms of property rights), was highly noticeable.

It is therefore necessary to set out the processes of political and institutional evolution that lay behind these changes and that, in part, explain them. An understanding of this sort is also crucial to describe the limits of this expansive wave. 
Open Access This chapter is licensed under the terms of the Creative Commons Attribution 4.0 International License (http://creativecommons.org/licenses/ by $/ 4.0 /$ ), which permits use, sharing, adaptation, distribution and reproduction in any medium or format, as long as you give appropriate credit to the original author(s) and the source, provide a link to the Creative Commons licence and indicate if changes were made.

The images or other third party material in this chapter are included in the chapter's Creative Commons licence, unless indicated otherwise in a credit line to the material. If material is not included in the chapter's Creative Commons licence and your intended use is not permitted by statutory regulation or exceeds the permitted use, you will need to obtain permission directly from the copyright holder.

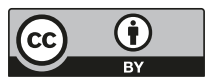

